\title{
Do you know what you eat? Students of the Medical University of Lublin and food consumption awareness
}

\author{
Patrycja Chylinska-Wrzos*, Marta Lis-Sochocka, Ewelina WaWryk-Gawda, \\ Kamila Bulak, Barbara JodlowsKa-JedryCh
}

Chair and Department of Histology and Embryology with Experimental Cytology Unit, Medical University of Lublin, Radziwiłłowska 11, 20-080 Lublin, Poland

\section{ARTICLE INFO}

Received 08 September 2015 Accepted 19 October 2015

\section{Keywords:}

modified food,

organic products,

young people.

\begin{abstract}
At the present time, consumers are paying more attention to the food items they purchase, and, hence, organic products, more and more, are a popular choice. Furthermore, there is an increased awareness of the ingredients added as fixatives and taste modifiers. Medical students are assumed to have greater health awareness, and to recognize that proper nutrition has a significant impact on the overall physical well-being. Moreover, they are thought to be aware of the chemical composition of consumed foods. The aim of our study was to truly assess the degree of consumer awareness amongst students of the Medical University of Lublin.

The research study consisted of 301 students of the I and II years, the work being performed at the turn of the year 2014/2015. The research tool was an anonymous questionnaire. This contained questions regarding their degree of healthy food awareness of retailed food products.

The results of this study revealed that about $44 \%$ of the respondents always or often pay attention to the composition of the food products which they buy. Indeed, the highest percentage of all respondents declared that their purchase of food products is guided by the declared (labeled) composition (48.84\% of the students coming from urban settings, and $55.81 \%$ coming from rural districts). Of note, regarding products labeled organic, from both urban and rural origin, such items were chosen by approximately $50 \%$ of the respondents. Finally, only a small percentage of students (about 9\% overall) stated that they avoid foods stated to contain preservatives.

In summary, despite the increasing availability of healthy foods, such items are not too often chosen by UM students - Indeed, despite the large biomedical knowledge purportedly held, medical students, in particular, do not avoid foods containing preservatives.
\end{abstract}

\section{INTRODUCTION}

The term "consumption" (lat. Consumptio), in general, means the purchasing and eating of food items, or the purchasing and usage of goods [2], however, in economic literature, there is no clear definition of the word. Basically, "consumption" can be defined as the act or process of meeting various human needs, and in this regard, the consumption of food is a fundamental physiological need of man [4]. The purchasing of such items is influenced by both internal and external factors. In addition, the sensation of hunger and appetite has substantial impact on the choice of a particular

\footnotetext{
* Corresponding author

e-mail: patrycja.wrzos@umlub.pl
}

food product, as does the individual preferences of the buyer. Affecting the latter are taste, culture, customs and traditions. The choice of product to consume is also influenced by gender, age, belief or social status [10]. In fact, the study undertaken by Krełowska-Kułas shows that certified organic food is more often procured by people with higher education and greater spending power [9].

Today, in a society more and more aware of the scope of rational nutrition, commercial food manufacturers have increased their competitiveness in the market by highlighting the health characteristics of their products, through pointing out the lack of added preservatives, as well as stressing the natural quality and ecology-positive aspects of their proffered food products $[4,5]$. 
With the Polish accession to the European Union, Poles have displayed an increasing interest in consuming organic food items. Such goods must meet certain technological and legal requirements for labeling and quality control. These are defined by national and European Union law $[3,6]$. Currently, to be certified as organic, such items must exclude the use of GMOs, agro-chemicals, antibiotics, growth promoters and hormones, and be without additives and chemical preservatives $[6,7,9]$. Since such goods are perceived to be more nutritious (with higher vitamin, mineral and protein content) and less carcinogenic, as well as more easily absorbed, organic food is thought of as being safe and healthy to consume $[3,7,9]$.

Unfortunately, despite the ever-growing environmental awareness of Polish society, the demand for certified organic commercial food items in Poland is still small. Yet it is increasing, the demand being lead by certain market segments thought of as being more aware. Therefore, medical students are the focus of our study, as they are generally perceived as being a group of people with greater health awareness, and who should know that proper nutrition has a significant impact on the overall physical well-being, as well as being thought of as having greater awareness of the chemical composition of foods consumed. Thus, the aim of our study was to assess food consumption awareness amongst students at the Medical University of Lublin. In our work, we wished to ascertain whether students pay attention to the stated composition of the foods which they buy during their daily shopping, as well as to understand the factors guiding the purchase. Furthermore, we wished to learn the degree of nutritional biomedical awareness held, particularly, the pattern of consumption of foods containing food preservatives.

\section{MATERIAL AND METHODS}

The work consisted of 301 students (201 women and 100 men) of the first and second year of full-time studies at the university. These individuals ranged in age from 19 to 27 years (median - 20 years). Among the young people, 215 people came from urban environs, and 86 from rural areas. The study were carried out at the turn of the year 2014/2015. The employed research tool was an anonymous questionnaire that included open questions and multiple choice questions. The questions concerned, among other notions, healthy food purchase and the type and degree of consumption awareness held.

The results were compiled by expressing the percentage of people who responded to individual questions in relation to whole target population. The results obtained were subjected to statistical analysis by way of the program Statistica 10.0 , using the $\mathrm{Chi}^{\wedge} 2$ Pearson at $\mathrm{p}<0.05$.

\section{RESULTS AND DISCUSSION}

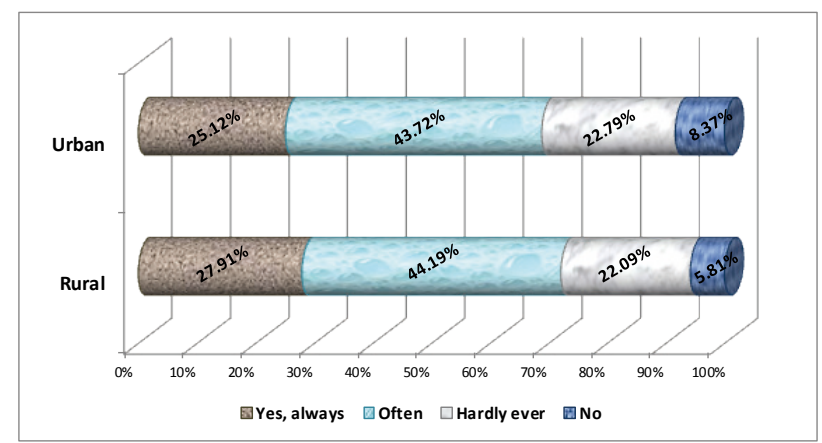

Figure 1. Do you pay attention to the composition of the foods which you buy? $(\mathrm{Chi} \wedge 2$ Pearsona: $0.963, \mathrm{df}=4, \mathrm{p}<0.91)$

To the question do you pay attention to the composition of the foods which you buy, the most of students said they do so often (Fig. 1.).

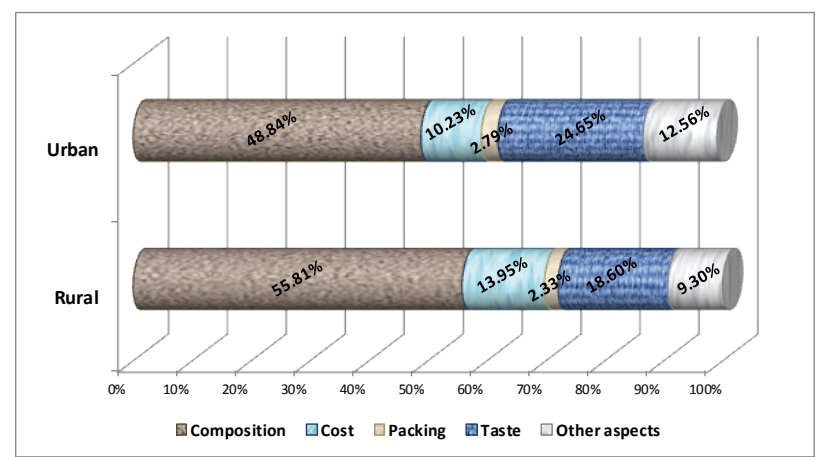

Figure 2. What is important to you when buying food products? $($ Chi^2 Pearsona: $8.52058, \mathrm{df}=8, \mathrm{p}<0.384)$

Regarding this question, the highest percentage of respondents declared that their purchase of food products is guided by their composition (Fig. 2.).

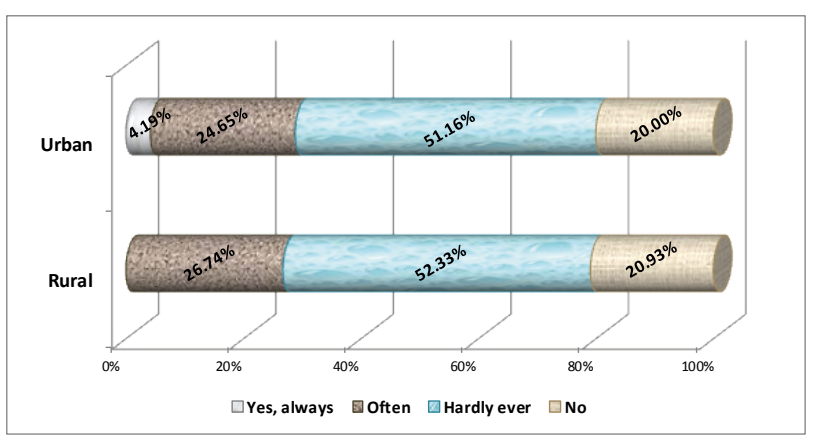

Figure 3. Do you eat certified organic foods? (Chi^2 Pearsona: $3.75, \mathrm{df}=5, \mathrm{p}<0.586$ )

Of the responses to this question, the greatest number of the surveyed indicated that they hardly ever purchase certified organic food products (Fig. 3.). 


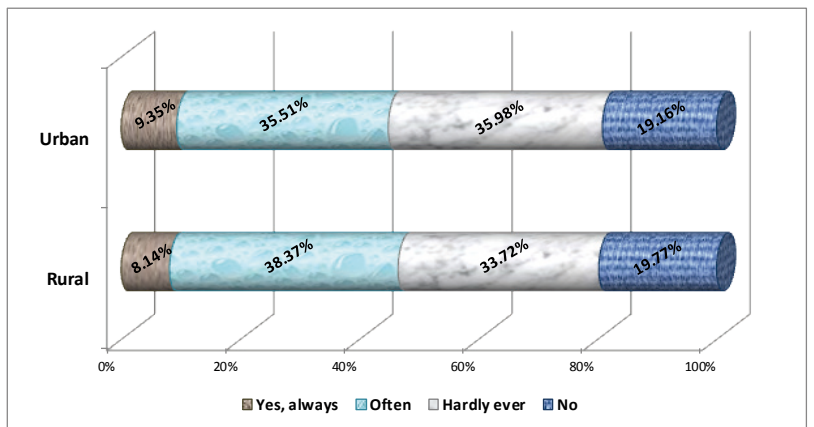

Figure 4. Do you avoid foods containing preservatives? (Chi^2 Pearsona: $2.354, \mathrm{df}=4, \mathrm{p}<0.670$ )

As to this question, approximately equal in choice were the categories 'often' and 'hardly ever' (Fig. 4.).

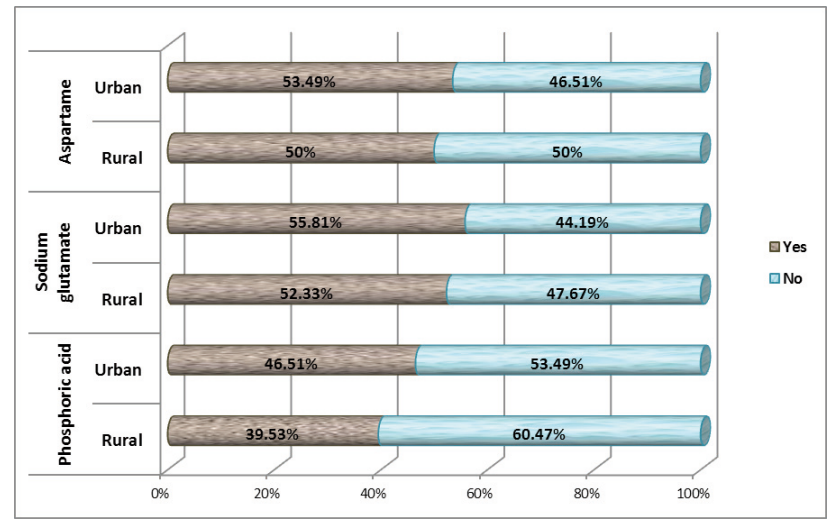

Figure 5. Are you aware of the use and consumption effects of aspartame, sodium glutamate and phosphoric acid?

Regarding this question, most were aware of the use and effects of aspartame consumption, and sodium glutamate, while the majority were unaware of the use and consumption effects of phosphoric acid (Fig. 5.).

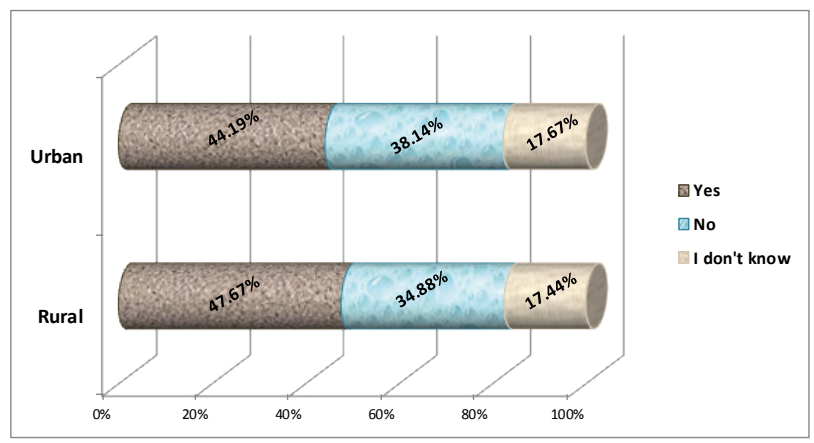

Figure 6. Do you think your diet is proper? $\left(\mathrm{Chi}^{\wedge}{ }^{\wedge}\right.$ Pearsona: $0.342, \mathrm{df}=2, \mathrm{p}<0.843)$

With reference to this question, the most of students said 'yes' (Fig. 6.).

Our research shows that regardless of place of living, the greatest percentage of students of Medical University of Lublin read the labels placed on the food products and paid attention to the ingredients contained within the food items which they buy. More than $43 \%$ of the urban-sourced respondents and slightly over $44 \%$ of those of rural origin put forward that they always read the ingredients of purchased food products. Few people responded that they never do (urban $-8.37 \%$, rural $-5.81 \%$ ). Sequentially, students were asked what is important when buying food products. Most students of urban origin (48.84\%) and from rural areas $(55.81 \%)$ said that they were guided by ingredient listing, while a little less stated that they did so by prior flavour experience (urban $-24.65 \%$, rural $-18.60 \%$ ) and price (urban $-10.23 \%$, rural $-13.95 \%$ ). Our results were akin to those seen in the study undertaken by Niewczas [10]. Here, most people also took into account the expiration date $93.7 \%$ of all respondents, price $-63.6 \%$, and, as in our work, product ingredient listing $-62.2 \%$ of respondents [10]. In our study, a significant proportion of urban-derived students $(12.56 \%)$ and rural-derived students $(9.30 \%)$ declared that they take into account other food product characteristics. Among these are caloric value, fiber content or brand.

Currently, in Poland, the increased availability of certified organic food items and the increased recognition of the hazards of GMOs and conventional food preservative ingestion has led to greater interest in healthy eating practices and choice of food item purchased. Unfortunately, this message has not been accepted by the first and second year students of the Medical Academy. The greater number, regardless of origin $(52 \%)$, do not choose certified organic produce. Indeed, at most, $25 \%$ alone do. Similar results were seen in the work undertaken by Kowalczuk-Vasilev et al. [7] in their 2010 questionnaire involving Lublin university students. In this, knowledge and purchase of certified organic food produce was co-related to year of study. In it, first and second year students were the least likely to purchase certified organic foods, while $20 \%$ of the third year students said they would or did, and $39 \%$ of the fourth year students indicated the same. However, only $25 \%$ of the fifth year students indicated this purchasing practice or would-be practice [7]. In the study undertaken by Koreleska and Pirogowska [6], the authors noted that the majority of respondents $(75.9 \%)$ do not buy certified organic food. However, a detailed analysis indicates that women more often buy healthy foods, as do young people up to 35 years of age and people with higher education [6]. These results are also confirmed by Grzybowska-Brzezińska [5], where only $12 \%$ of respondents declared that they regularly buy certified organic food [5].

Because students of the medical faculty should have a good biomedical knowledge and should display some care about healthy eating practices, follow-up questions were related to their held knowledge of the most commonly used preservatives or flavor enhancers utilised in the processed food industry. The results of this part of the questionnaire did not show a dependency on the urban/rural origins of the sample population $(\mathrm{p}<0.670)$, but did indicate that about half the students knew something about these additives. As to whether the sampled population intentionally avoided processed food products with particular preservatives, $35.51 \%$ of those originating from urban areas did so, while $38.37 \%$ of those of rural origin did so often. Unfortunately, a similar percentage of respondents replied that that they almost never followed such a practice (urban $-35.98 \%$, rural $-33.72 \%$ ). Furthermore, only slightly more than $9 \%$ of all urban students and $8.14 \%$ of all rural students chose to answer "I always avoid foods containing preservatives". Similar results were obtained by Antoniak and Danowska-Oziewicz [1]. In 
this work, the authors took into account gender and course of study. Their research indicated that $31.6 \%$ of all respondents only sometimes avoided foods containing preservatives, and, in regard to gender, women were a slight majority. Of note, when broken down into course of study, $40 \%$ of those who intentionally avoided foods containing certain preservatives were students of the Faculty of Food Science [1]. The work of Niewczas [10] confirms these results. In this study, the author also took into account gender, place of residence and education level. Herein, more women avoided processed foods containing particular preservatives $(71.6 \%)$, as did people aged over 40 years $-38.2 \%$, and urban dwellers $38.9 \%[10]$.

We also asked students if they had an awareness of the uses in the processed food industry, of aspartame, sodium glutamate and phosphoric acid, as well as the effects of their consumption. Almost equally, urban and rural students had a recognition of the practices of the addition of aspartame, as well as some knowledge of its effects upon ingestion (urban $-53.49 \%$, rural $-50 \%$ ), as well as that of sodium glutamate (urban $-55.81 \%$, rural $-52.33 \%$ ). However, a slightly smaller proportion of those sampled had knowledge of phosphoric acid addition (urban $-46.51 \%$, rural $-39.53 \%$ ). In the Krejpcio et al. study [8], which tested the knowledge of students from two different universities in Poznan regarding such additives and flavour enhancers, the results regarding aspartame differed. Therein, $97 \%$ of students from the Food Technology and Human Nutrition program, and $90 \%$ of those within the Nutrition program, had some knowledge. However, among students drawn from the Faculty of Civil Engineering, only 13\% had awareness of aspartame addition and ingestion. The results of these studies underline that the knowledge of food additives and enhancers mainly depends on the profile of education [8].

Because it is well recognized that a healthy and well balanced diet is the basis for the proper development and function of the body, we asked the sample population whether they think their diet is appropriate and adequate. Most respondents stated that this was so (44\% urban, $47 \%$ rural).

\section{CONCLUSION}

In conclusion, the results of our study indicate that the place of origin (urban versus rural) does not affect the food consumption preferences of students of the Medical University of Lublin, yet, the ingredient listing and previous taste experience does. Moreover, despite the growing popularity and availability of certified organic food products, such items are rarely consumed by medical students. What is more, in the sampled population, knowledge of the use of, and the effects upon ingestion of common preservatives, food additives and flavour enhancers is not at a great level. Despite the purported large biomedical knowledge of such medical students, they do not avoid foods containing particular preservatives. Yet, irrespective of the place of origin, they believe that their diet is appropriate.

The results of our study indicate that first and second year students do not have sufficient knowledge of healthy and rational nutritional practices. This may be due an inappropriate and too general curriculum in primary and secondary schools. Remedial steps, must, therefore, be undertaken, and health and nutrition studies should be introduced or enhanced in the pre-university/pre-higher years of learning.

\section{REFERENCES}

1. Antoniak L., Danowska-Oziewicz M.: Knowledge and opinions of students on additives used in food production. Pol. J. Natur. Sc., 29(3). 2014.

2. Bywalec C. (2010). Konsumpcja a rozwój gospodarczy i społeczny. In: Ekonomia. Perzyńska J. (editor). Warszawa: p.12.

3. Gadomska J., Sadowski T., Buczkowska M.: Ekologiczna żywność jako czynnik sprzyjający zdrowiu. Probl Hig Epidemiol., 95(3), 2014.

4. Grzelak A., Gałązka M.: Związki potrzeb, popytu i konsumpcji żywności- ujęcie teoretyczne. http://www.kpsw.edu.pl/pobierz/ wydawnictwo/re4/37_grzelak_galazka.pdf (available: 20.08.2015).

5. Grzybowska-Brzezińska M.: Świadomość ekologiczna konsumentów a ich zachowania na rynku żywności. Studies \& Proceedings of Polish Association for Knowledge Management, 51, 2011.

6. Koreleska E., Pirogowska E.: Źródła informacji oraz wiedza mieszkańców Bydgoszczy na temat żywności ekologicznej. POLSKIE STOWARZYSZENIE ZARZĄDZANIA WIEDZĄ Seria: Studia $i$ Materiały, 66, 2013.

7. Kowalczuk-Vasilev E., Klebaniuk R., Gronowicz K.: Żywność ekologiczna w opinii studentów różnych lat studiów uczelni lubelskich. Probl Hig Epidemiol., 92(4), 2011.

8. Krejpcio Z., Suliburska J., Hyżyk A.H., Dyba S., Skwarek K.: Ocena poziomu wiedzy na temat dodatków do żywności oraz ich spożycia w wybranych grupach studentów. Bromat. Chem. Toksykol., XLIV, 3, 2011.

9. Krełowska-Kułas M.: Preferencje konsumentów związane ze spożywaniem żywności ekologicznej. Zeszyty Naukowe Akademii Ekonomicznej w Krakowie, 743, 2007.

10. Niewczas M.: Kryteria wyboru żywności. ŻYWNOŚĆ. Nauka. Technologia. Jakość, 6 (91), 2013. 